\author{
Adrian Borys \\ Wydział Prawa, Administracji i Ekonomii, Uniwersytet Wrocławski \\ borys.adrian.93@gmail.com
}

\title{
Ewolucja polskiego prawa upadłościowego w ujęciu ogólnego schematu badań historycznoprawnych
}

\author{
The evolution of Polish bankruptcy law in the context of the general \\ scheme of historical and legal research
}

\section{STRESZCZENIE}

W artykule przedstawiono analizę ewolucji polskiego prawa upadłościowego. W pierwszej części omówiono wykorzystany model badawczy stosowany w naukach historyczno-prawnego. Model ten odwołuje się do idealizacyjnej koncepcji nauki. Przedstawione zostały trzy podstawowe etapy rozwoju polskiego prawa upadłościowego. Dokonana analiza historyczno-prawna dotyczy zarówno aktów prawnych, jak i wiedzy pozaźródłowej, którą jest między innymi znajomością warunków ekonomicznych. Artykuł pokazuje, że nie można zrekonstruować treści normatywnych danego aktu prawnego w oderwaniu od warunków społecznych i ekonomicznych, które istnieją w czasie jego obowiązywania i stosowania. Na podstawie analizy rozwoju prawa upadłościowego w polskim ustawodawstwie sformułowane zostały dwa zasadnicze kierunki dalszego rozwoju tej dziedziny prawa. Pierwszy wskazuje na prymat postępowania restrukturyzacyjnego (naprawczego) mającego na celu zachowanie sprawnie działającego przedsiębiorstwa dłużnika. Drugi, dotyczy rozszerzenia podmiotowego zakresu postępowań upadłościowych oraz restrukturyzacyjnych, na podmioty, które nie prowadzą działalności gospodarczej. Czas pokaże, czy te trendy są właściwe oraz czy przyczynią się do osiągnięcia zakładanych celów.

Słowa kluczowe: prawo upadłościowe, historia prawa, ewolucja instytucji prawa upadłościowego, transformacja ustrojowa.

\section{UWAGI WPROWADZAJĄCE}

Prawo, to pojęcie teoretyczne i może być różnie definiowane, stąd pojawiają się spory i nieporozumienia terminologiczne. Na potrzeby niniejszego opracowania siatka pojęciowa została zaczerpnięta z tzw. poznańskiej szkoły teorii 
prawa ${ }^{1}$. Dlatego też w opracowaniu przyjęta zostało derywacyjna koncepcja wykładni² ${ }^{2}$, która zakłada dualistyczną strukturę prawa. Pierwszy element, to przepis lub zbiór przepisów (tekst prawny) stanowiące strukturę dostępną postrzeganiu bezpośredniemu (struktura powierzchniowa prawa). Natomiast pod tą strukturą kryje się struktura, którą tworzy norma lub uporządkowany systemowo zbiór norm, dostępnych dzięki poznaniu w procesie interpretacji (struktura głęboka praw).

Dla potrzeb niniejszego opracowania termin „prawo” oznaczać będzie system norm prawnych. Norma jest to wypowiedź dyrektywalna, nakazująca lub zakazująca określonym podmiotom (adresatom normy) postępowania w określony sposób (zakres normowania) w określonej sytuacji (zakres zastosowania) ${ }^{3}$. Norma prawna jest to element struktury głębokiej, która jest dostępna dopiero w procesie interpretacji ${ }^{4}$.

Prawo upadłościowe jest to kluczowy element dziedziny prawa, określanej mianem prawa insolwencyjnego (,prawa o niewypłacalności”), która zajmuję się skutkami prawnymi niewypłacalności oraz etapem go poprzedzającym, czyli stanem zagrożenia niewypłacalnością ${ }^{5}$. Przedmiotem regulacji prawa upadłościowego jest stan faktyczny, w którym zasada pacta sunt servanda nie może być dłużej realizowana, a przynajmniej nie ma możliwości jej zrealizowania w całości wobec wszystkich wierzycieli ${ }^{6}$. Konieczne są odpowiednie procedury, ponieważ konkurencja wierzycieli, którzy korzystaliby z istniejących mechanizmów egzekucji sądowej lub egzekucji administracyjnej, mogłaby doprowadzić do niesprawiedliwego zróżnicowania ich sytuacji pod kątem możliwości zaspokojenia swoich roszczeń.

W rozwoju polskiego prawa upadłościowego wyróżnić można trzy etapy. Przepisy prawa upadłościowego państw zaborczych obowiązywały w niepodległej Polsce dość długo, gdyż aż do 1935 roku. Przygotowania do kodyfikacji jednolitego prawa upadłościowego rozpoczęły się co prawda już w roku 1930, jednakże dopiero 1 stycznia 1935 r. weszły w życie dwa rozporządzenia Prezydenta Rzeczypospolitej regulujące omawianą materię. Wobec tego, pierwszy etap rozwoju polskiego prawa

1 Zob. Z. Ziembiński, Problemy podstawowe prawoznawstwa, Warszawa 1980; M. Zieliński, Interpretacja jako proces dekodowania tekstu prawnego, Poznań 1972, s. 23 i n.

2 Zob. szerzej M. Zieliński, Właściwości derywacyjnej koncepcji wykładni [w:] Zeszyty Naukowe Uniwersytetu Szczecińskiego. Roczniki Prawnicze, 1998, nr 2, s. 10.

3 A. Bator [w:] Wprowadzenie do nauk prawnych. Leksykon tematyczny, red. A. Bator, Warszawa 2012, s. 143.

4 Przy przyjęciu dualistyczne ontologii prawa, co jest typowe dla szkoły poznańskiej i dyrektywnalnej koncepcji wykładni.

5 A.J. Witosz [w:] System prawa handlowego, tom 6, Prawo restrukturyzacyjne i upadtościowe, red. A. Hrycaj, A. Jakubecki, A. Witosz, Warszawa 2016, s. 616.

6 Ibidem. 
insolwencyjnego ${ }^{7}$, to okres międzywojenny, w którym polskie ustawodawstwo insolwencyjne opierało się na konstrukcji dwóch postępowań. Jednego uregulowanego przez Rozporządzenie Prezydenta Rzeczypospolitej z dnia 24 października 1934 r. Prawo upadłościowe ${ }^{8}$ (dalej: PrUpad34), które operowało kategoriami zbiorowej egzekucji prowadzonej w stosunku do niewypłacalnego dłużnika, z ograniczoną możliwością zwarcia układu z wierzycielami. Drugie postępowanie insolwencyjne, w tym okresie, uregulowane było w Rozporządzeniu Prezydenta Rzeczypospolitej z dnia 24 października 1934 r. Prawo o postępowaniu układowem ${ }^{9}$ (dalej. PrUkła). Postępowanie to miało zapobiegać ogłoszeniu upadłości, dzięki możliwości restrukturyzacji zadłużenia ${ }^{10}$. Przedmiotowe rozporządzenia zostały zharmonizowane z międzywojennym polskim systemem prawa, w szczególności dotyczącym obrotu gospodarczego, m. in. $\mathrm{z}$ Kodeksem handlowym ${ }^{11} \mathrm{z}$ dnia 27 czerwca 1934 r. oraz obowiązywały prawie 70 lat, bo aż do 1 października 2003 r. ${ }^{12}$.

Następny okres w ewolucji polskiego prawa insolwencyjnego, stanowi przedział czasu od wejścia w życie ustawy z dnia 28 lutego 2003 r. Prawo upadłościowe i naprawcze (dalej: PrUpadNapr) do jej nowelizacji z maja 2015 r. ${ }^{13}$.

Ostatni okres ewolucji prawa insolwencyjnego, to czas od wskazanej nowelizacji, która doprowadziła do rozdzielenia regulacji zawartej dotychczas w PrUpadNapr na dwa odrębne akty prawne. Obecnie w polskim porządku prawnym funkcjonują dwie ustawy regulujące problematykę prawa insolwencyjnego, jest to Ustawa z dnia 15 maja 2015 r. - Prawo restrukturyzacyjne ${ }^{14}$ (PrRest) oraz Ustawa z dnia 28 lutego 2003 r. Prawo upadłościowe ${ }^{15}$ (dalej: PrUpad).

Na przykładzie tych regulacji można zaobserwować ewolucje prawa upadłościowego jako formy zbiorowej egzekucji oraz wpływ warunków społecznych i ekonomicznych na kształt regulacji prawnej. Ewolucja ta stanowi dobry przedmiot badań historycznoprawnych, zwłaszcza przy wykorzystaniu ogólnego modelu badań, który pozwala na uwzględnienie również wiedzy pozaźródłowej w badaniach historycznoprawnych. Dzięki temu można uwzględnić wpływ warunków ekonomicznych i społecznych na regulacje prawną.

7 Sformułowanie prawo insolwencyjne w niniejszym opracowaniu wykorzystane jest dla zaborczego określenia postępowań upadłościowych, naprawczych i restrukturyzacyjnych.

8 t.j. Dz.U. z 1991 r. Nr 118, poz. 512 ze zm.

9 t.j. Dz.U. z 1934 r. Nr 93, poz. 836 ze zm.

10 A.G Harla, Prawo upadtościowe i naprawcze. Zarys wykładu, Warszawa 2011, s. 39.

11 Rozporządzenie Prezydent Rzeczypospolitej z dnia 27 czerwca 1934 r. Kodeks handlowy (Dz.U. z 1934 r. Nr 57, poz. 502 ze zm.).

12 M. Koenner, Syndyk masy upadłości, Sopot 1999, s. 18.

13 Dz.U. 2015 poz. 978.

14 t.j. Dz. U. z 2017 r. poz. 1508 ze zm.

15 t.j. Dz. U. z 2017 r. poz. 2344 ze zm. 


\section{METODOLOGIA HISTORYCZNOPRAWNA W UJĘCIU KONCEPCJI IDEALIZACYJNEJ NAUKI}

Dla dalszych rozważań istotne jest określenie charakteru badań historycznych w prawoznawstwie. Badania historycznoprawne nie koncentrują się na opisywaniu języka, przedmiotem takich badań jest rzeczywistość, a dokładniej rzeczywistość prawna. Oznacza to, że badaniom historyków prawa można przypisać charakter empiryczny, pogląd ten jest jednak sporny ${ }^{16}$. Charakteru empirycznego nie można będzie przypisać wszystkim badaniom prawa. Jeżeli takie badanie polega jedynie na stosowaniu usystematyzowanych procedur służących przekształcaniu tekstu prawnego, w normy prawne pojmowane jako twory językowe o pożądanych cechach formalnych. Przykładowo można wskazać, że takie ujęcie badania prawa wystąpi w przypadku stosowania analitycznej koncepcji wykładni, w której twierdzenia interpretacyjne maksymalizują wartość przedmiotu interpretacji. Twierdzenia interpretacyjne, w tym ujęciu, nie opisują rzeczywistości, ale optymalizują tekst prawny, dlatego nie mają statusu semantycznego. Nie tworzą zdań w sensie logicznym, a w konsekwencji badania oparte na takiej metodzie nie mają charakteru empirycznego. W badaniach historycznoprawnych może również wystąpić taka strategia poznawcza, badacz może jedynie czysto pojęciowo analizować terminy występujące w tekstach prawnych, badać ich zakres znaczeniowy oraz wzajemne relacje ${ }^{17}$.

Przyjmując, że historia prawa, ujmowana jako część nauk historycznych, zajmuje się przeszłymi faktami historycznymi, można zanegować podejścia ograniczające się jedynie do analizy tekstów prawnych ${ }^{18}$. Oczywiście przy założeniu, że przeszłość „istniała", a za pośrednictwem źródeł historycznych jest poznawalna. W tym ujęciu czyni się jednak pewne uproszczenie, polegające na przyjęciu, że fakty historyczne to zjawiska obserwowalne ${ }^{19}$, takie jak zmiany w środowisku przyrodniczym, zachowania ludzi, przekształcenia kulturowe w społeczeństwie. Jednakże wśród faktów historycznych obok faktów obserwowalnych, wyróżnia się również fakty nieobserwowalne, opisywane za pomocą tzw. predykatów teoretycznych, które nie podlegają bezpośrednio weryfikacji empirycznej, jednakże stwierdzają pewne cechy rzeczywistości ${ }^{20}$. Przyjąć należy, że przedmiotem badań

16 Zob. L. Nowak, Interpretacja prawnicza. Studium z metodologii prawoznawstwa, Warszawa 1973, s. 170-173.

${ }^{17}$ M. Zajęcki, Przedmiot badań nauk historycznoprawnych (na przykładzie pokoju augsburskiego jako fenomenu historycznego i prawnego) [w:] CUIUS BEGIO, EIUS RELIGIO? Zjazd Historyków Państwa i Prawa, Lublin 2006, s.148.

18 Ibidem.

19 Przejaw realizmu naiwnego - pogląd o istnieniu świata fizycznego w dosłownym sensie, przy jednoczesnym braku refleksji nad epistemologicznymi podstawami uznawania tego poglądu.

20 J. Pomorski, W poszukiwaniu modelu historii teoretycznej, Lublin 1984, s. 48-50. 
historycznoprawnych są dawne regulacje prawne, ujmowane jako fakty historyczne nieobserwowalne, używane jednak do opisu rzeczywistości społecznej ludzi, którzy te regulacje tworzyli, stosowali albo przynajmniej rozważali ich potencjalną przydatność ${ }^{21}$.

Zdaniem polskiego filozofa $L$. Nowaka najbardziej odpowiednią metodą do naukowego spojrzenia na rzeczywistość jest metoda idealizacji i konkretyzacji, która zakłada, że rozpatrywane zjawisko jest warunkowane przez pewien zbiór czynników ${ }^{22}$. Czynniki te są zróżnicowane ze względu na ich wpływ na badane zjawisko, wskazuje się czynniki główne oraz czynniki uboczne ${ }^{23}$. Wyjaśnienie danego problemu badawczego w tej metodzie polega na ujawnieniu całej struktury esencjalnej i skonstruowanie prawa naukowego, które opisuje badane zjawisko.

Stosując opisaną procedurę, badacz w pierwszej kolejności dokonuje idealizacji, uznając, że czynniki uboczne nie mają żadnego wpływu na badane zjawisko. W sformułowaniu prawa naukowego uwzględniane będą jedynie czynniki główne. W następnej kolejności badacz dokonuje konkretyzacji, czyli uchyla poczynione wcześniej założenie idealizujące i formułuje zmodyfikowane prawa nauki, które obejmują już wpływ czynników ubocznych. Jeżeli w danym badaniu pojawiają się czynniki uboczne, których wpływu na badane zjawisko nie można jednoznacznie określić, to należy skorzystać z procedury aproksymacji, polegającej na przybliżonym oszacowaniu wpływu pozostałych czynników ubocznych.

Kategoria badań empirycznych na gruncie historii prawa jest specyficzna, są to badania humanistyczne. Niemniej przedstawiony model wyjaśniania faktów empirycznych można wykorzystać także do wyjaśniania zachowań ludzkich. Procedura taka określana jest mianem interpretacji humanistycznej ${ }^{24}$. Problem naukowy w metodzie interpretacji humanistycznej polega na udzieleniu odpowiedzi na pytanie, dlaczego osoba X postąpiła w określony sposób Z. Dla rozważania takiego problemu badawczego w pierwszej kolejności należy przyjąć założenie o racjonalności osoby $\mathrm{X}$, które przyjmuje uproszczoną postać: , jeżeli osoba $\mathrm{X}$ ma do wyboru jedną z czynności $\mathrm{C}_{1}, \mathrm{C}_{2}, \ldots, \mathrm{C}_{\mathrm{n}}$ (wzajemnie wykluczających się), to wykona czynność, której rezultat jest przez X-a najbardziej preferowany" ${ }^{25}$. Przyjmujemy tutaj pojęcie racjonalności instrumentalne, tzn. uznajmy dany podmiot za racjonalny, jeżeli jego działania są optymalne ze względu na założone cele. Interpretacja humanistyczna, jeżeli chodzi o metodologię, polega na zrekonstruowaniu fragmentu wiedzy oraz fragmentu preferencji danej osoby. Tak rozumiane wiedza i preferencje są strukturą

${ }^{21}$ M. Zajęcki, op. cit., s.148.

${ }^{22}$ Jest to z założenie ontologiczne o istnieniu struktury esencjalnej, zob. L. Nowak, Wstęp do idealizacyjnej teorii nauki, Warszawa 1977, s. 44.

${ }^{23}$ L. Nowak, op. cit., s. 50.

${ }^{24}$ Zob. szerzej W. Patryas, Idealizacyjny charakter interpretacji humanistycznej, Poznań 1979;

J. Kmita, Wykłady z logiki i metodologii nauk, s. 16 i n.

${ }^{25}$ J. Kmita, op. cit., s. 16. 
esencjalną wyjaśnianego zjawiska, problemu badawczego w postaci „X zachował się w sposób Z". Przedstawiona formuła J. Kmity idealizuje rzeczywiste procesy psychologiczne, które wpływają na zachowanie ludzi. System wiedzy i preferencji ludzi jest jednak bardziej skomplikowany ${ }^{26}$.

Możliwość zastosowania interpretacji humanistycznej w prawoznawstwie, wynika $\mathrm{z}$ faktu, iż pojedynczego człowieka można w tej interpretacji zastąpić innym podmiotem, któremu można przypisać wiedzę oraz preferencje. Takim podmiotem abstrakcyjnym jest ,prawodawca doskonały” ${ }^{27}$, któremu w procesie wykładni przypisuje się autorstwo prawa ${ }^{28}$. Prawodawca doskonały w prezentowanym ujęciu idealizacyjnym jest to podmiot racjonalny zarówno wewnętrznie jak i zewnętrznie.

Teorią realizującą w metodologii historycznej wskazane powyżej założenia ogólnometodologiczne oraz historyczne jest teoria J. Topolskiego ${ }^{29}$. Koncepcja ta $w$ pierwszej kolejności odrzuca naiwny realizm w badaniach historycznych ${ }^{30}$. Podstawowym założeniem wskazanej koncepcji jest założenie, że wyjaśnia dawne zjawiska, a nie jedynie je opisuje i próbuje zrozumieć. Wyjaśnianie rzeczywistości historycznej następuje $w$ dwóch ptaszczyznach ${ }^{31}$. Z jednej strony, badaniu podlegaja zachowania poszczególnych postaci historycznych, z drugiej natomiast istote wielkich procesów dziejowych bada się abstrahując od dziatań poszczególnych ludzi. Badania w pierwszej płaszczyźnie polegaja na interpretacji humanistycznej, natomiast $w$ drugiej na tworzeniu teoretycznych modeli wyjaśniajacych zjawisko, a w konsekwencji na zrekonstruowaniu idealizacyjnych praw nauki z dziedziny historii politycznej, społecznej, gospodarczej, oraz prawnej.

Przed dalszą analizą należy określić ontologie „prawa” na gruncie nauk historycznoprawnych, oczywiście przez pryzmat wyżej poczynionych założeń. Najbardziej odpowiednia będzie w tym przypadku socjologiczna definicja prawa jako podsystemu struktury społecznej, regulującego zachowania ludzkie poprzez zinstytucjonalizowane tworzenie i egzekwowanie, przez kompetentne organy, nakazów i zakazów ${ }^{33}$.

26 M. Zajęcki, op. cit., s. 150.

27 Konstrukcja prawodawcy doskonałego oparta jest na założeniach idealizacyjnych, typowych dla idealizacyjnej interpretacji dogmatyki prawa. Złożenie idealizacyjne (upraszczające, kontrfaktyczne) dotyczące doskonałego prawodawcy można podzielić na założenia ogólne (założenie, iż prawodawca to jeden podmiot oraz założenie o racjonalności instrumentalnej prawodawcy) oraz założenia szczegółowe dotyczące wiedzy i preferencji prawodawcy.

28 S. Wronkowska, Z. Ziembiński, Zarys teorii prawa, Poznań 2001, s. 163-164.

29 J. Topolski, Teoria wiedzy historycznej, Poznań 1983, s. 376.

30 Ibidem; A. Zalewska, Teoria źródła archeologicznego i historycznego we współczesnej refleksji metodologicznej, Lublin 2005, s. 41.

31 J. Topolski, op. cit., s. 376 i n.

32 Ibidem.

33 w rozważaniach nad procesem dziejowym warto posługiwać się terminem ,prawo" w znaczeniu socjologicznym, a nie jurydycznym, zob. W. Kula, Problemy i metody historii gospodarczej, 
Na przedstawionych powyżej założeniach formułuję się ogólny schemat badań historycznoprawnych ${ }^{34}$. Schemat ten składa się z trzech etapów:

1. opisu systemów norm prawych w wybranych ramach (rzeczowych, przestrzennych i czasowych).

2. wyjaśnieniu procesów prawodawczych prowadzących do tworzenia systemów prawnych wskazanych w punkcie 1 .

3. uogólnieniu prawidłowości rządzących procesami prawodawczymi i poszukiwanie, docelowo, praw nauki rządzących ewolucją systemów prawnych.

\section{WYKORZYSTANIE OGÓLNEGO MODELU BADAŃ HISTORYCZNOPRAWNYCH DO BADANIA HISTORYCZNYCH EWOLUCJI POLSKIEGO PRAWA UPADŁOŚCIOWEGO}

\section{Opis systemów norm prawnych w wybranych ramach rzeczowych, przestrzennych i czasowych}

Pierwszy etap ogólnego modelu badań historycznoprawnych, to rekonstrukcja określonego systemu prawnego, która polega na badaniach faktograficznych ${ }^{35}$, czyli zbieraniu informacji o czynnościach uznawanych, na gruncie wiedzy pozaźródłowej, za czynności prawodawcze i o wytworach tych czynności, czyli tekstach prawnych ${ }^{36}$. Wiedza pozaźródłowa wykorzystywana jest do zinterpretowania tekstów prawnych lub zinterpretowania zachowań ludzkich spowodowanych prawem niepisanym, a w konsekwencji wyznaczenie porządku prawnego w ramach określonych przez przedmiot badania. Następnie badacz powinien określić w jakim czasie i na jakim terytorium obowiązywał tak zrekonstruowany zbiór norm.

Badanie polskiego prawa upadłościowego realizowane zgodnie z ogólnym modelem badań historycznoprawnych należy rozpocząć od rekonstrukcji treści normatywnej dwóch aktów prawnych obowiązujących w pierwszym etapie jego rozwoju. Zgodnie z tym co zostało wskazane we wstępie niniejszego opracowania będzie to PrUpad34 oraz PrUkła. Przedmiotowe akty prawne funkcjonowały aż do 2008 r., tzn. przez okres międzywojenny, okres polski ludowej oraz już w okresie po przemianach społeczno-gospodarczych, które nastąpiły w 1989 r. Rekonstruując treść normatywną wskazanych aktów prawnych należy wykorzystać wiedzę pozaźródłową, którą będzie między innymi wiedza o uwarunkowaniach gospodarczych. Przez inny pryzmat będzie rekonstruowana treść normatywna w okresie Polskiej Rzeczpospolitej Ludowej, gdzie funkcjonowała społeczna własność środków produkcji, a przez inny po roku

\footnotetext{
Warszawa 1983, s. 66;. L. Nowak, U podstaw teorii socjalizmu, Poznań 1991, s. 182.

${ }^{34}$ M. Zajęcki, op. cit., s. 156.

35 Ibidem, s. 157.

${ }^{36}$ Co do zasady są to teksty prawne, mogą być to równie dokumenty urzędowy jak i prywatne.
} 
1989, czyli w okresie gospodarki wolnorynkowej. Dokonując badania historycznoprawnego z wykorzystaniem powyżej wskazanej wiedzy pozaźródłowej, zaobserwować można dynamizm w rozwoju prawa upadłościowego, przy niezmienności podstawowych aktów prawnych reagujących tę dziedzinę prawa. W tym przypadku szczególnie istotna jest omówiona wcześniej koncepcja wykładni dyrektywalnej ${ }^{37}$. Wskazać należy, że międzywojenne uregulowania prawa upadłościowego, co prawda pozostały w mocy aż do początku dwudziestego pierwszego wieku, jednakże okres ich efektywnego obowiązywania zakończył się wraz z wybuchem II wojny światowej. W okresie powojennym, przez ponad czterdzieści lat, prawo upadłościowe stanowiło bowiem w zasadzie martwą dziedzinę prawa, co wiązało się z obowiązującym w Polskiej Rzeczpospolitej Ludowej systemem nakazowo-rozdzielczym ${ }^{38}$.

Sytuacja radykalnie zmieniła się wraz z transformacją ustrojową, do której doszło na przełomie lat osiemdziesiątych i dziewięćdziesiątych dwudziestego wieku. Regulacje przyjęte w przedwojennym prawie upadłościowym nie odpowiadały jednak nowej sytuacji społeczno-gospodarczej, zarówno w warstwie pojęciowej, jak i również w warstwie merytorycznej. Regulacja ta, formalnie obowiązywała od $1935 \mathrm{r}^{39}$, w nowym systemie gospodarczym była mało przydatna, a niekiedy wręcz szkodliwa. Podjęte próby udoskonalenia unormowań z 1934 r. podejmowane w latach 90. ubiegłego wieku traktować należy jako nieudane. Nie osiągnięto bowiem zamierzonego celu w postaci dostosowania „starego" ustawodawstwa do obecnych czasów.

W rozważanym modelu badań historycznoprawnych wiedza o systemie społeczno-gospodarczym stanowi ważną wiedzę pozaźródłową, dzięki której opis systemu prawa insolwencyjnego będzie pełniejszy. Jeżeli badacz nie uwzględniłby wskazanych elementów pozaźródłowych dokonałby niepoprawnej rekonstrukcji treści normatywnej przepisów prawa upadłościowego.

Wiedzą pozaźródłową będzie również wiedza o języku, należy zauważyć, iż w roku 1934, czyli roku uchwalenia wskazanych aktów prawnych, funkcjonowały odmienne niż w obecnych czasach reguły semantyczne i syntaktyczne w języku polskim. Warto zwrócić uwagę na fakt, że wiedza ta - zgodnie z koncepcją $J$. Topolskiego - może być potoczna lub naukowa ${ }^{40}$. W pierwszym przypadku historyk prawa dokonując analizy tekstu PrUpad34 i PrUkła posłuży się swoją znajomością współczesnego języka polskiego lub skorzysta z popularnych opracowań dotyczących historii języka polskiego. W drugim przypadku, badacz przed analizą stricte

37 Zob. szerzej M. Zieliński, Interpretacja jako proces dekodowania tekstu prawnego, Poznań 1972, s. 24, M. Zirk-Sadowski, Prawo a uczestniczenie w kulturze, Łódź 1998, s. 12 i n.

38 Zob. Z. Świeboda, Komentarz do prawa upadłościowego i prawa o postępowaniu układowym, Warszawa 1996, s. 3.

${ }^{39}$ przy przyjęciu koncepcji obowiązywania systemowego.

40 Zob. J. Topolski, op. cit., s. 376 i n. 
prawniczą uzupełni wiedzę o znajomości polskiego języku prawnego z okresu międzywojennego z fachowych opracowań monograficznych lub słownikowych.

\section{Wyjaśnienie procesów prawodawczych prowadzących do tworzenia danych systemów norm prawnych}

Drugi etap ogólnego modelu badań historycznoprawnych polega na udzieleniu odpowiedzi na pytanie, dlaczego prawodawca (określony podmiot) uregulował daną kwestię w taki, a nie inny sposób. W tym celu konieczna jest znajomość jego wiedzy i preferencji. Prawodawcę należy rozumieć w tym przypadku socjologicznie, a jego działania wyjaśnić w drodze interpretacji humanistycznej ${ }^{41}$. Badania te charakteryzują się większą koncentracją na elementach dynamicznych analizy, czyli przeobrażaniom danego fragmentu systemu prawa w dłuższej prospektywnie czasowej. Badania te nie koncentrują się wyłącznie na elementach statycznych analizy, takich jak akt prawny i jego treść.

W zależności od założeń przyjętych w danych badaniach, możliwe jest kontynuowanie wyjaśniania działań prawodawców w sensie socjologicznym lub odejście od analizy motywacji konkretnych ludzi, a przez co stworzenie swoistego modelu rozwoju danej instytucji prawnej ${ }^{42}$. Wybór ten zależy od przyjętej przez badacza historiozofii ${ }^{43}$.

Do problemów badawczych w drugim etapie można zaliczyć zarówno analizy działań jednostek, jak i analizy procesów dziejowych. W pierwszej z wyróżnionych grup problemów, historyk prawa będzie stawiał sobie pytanie: jakimi motywami kierowali się twórcy danej regulacji prawnej? Należy więc odpowiedzieć jaki był cel wprowadzenia do obrotu prawnego danej regulacji prawnej. Zagadnienie to jest szczególnie istotne w przypadku, w którym następowała nowelizacja lub reforma określonej dziedziny prawa.

Jak już zostało zasygnalizowane, po transformacjach ustrojowych przełomu lat osiemdziesiątych i dziewięćdziesiątych, regulacja międzywojenna zawarta w dwóch rozporządzeniach przestała odpowiadać nowym realiom społeczno-gospodarczym. Konsekwencją anachronicznej regulacji były liczne nowelizacje. Jednakże na tym etapie nie zmieniono głównych założeń filozofii prawa upadłościowego, jedynie usiłowały dostosowywać je do zmian w ustawodawstwie, szczególnie w zakresie postępowania cywilnego ${ }^{44}$. W gospodarce wolnorynkowej sprawne postępowania upadłościowe stanowią niezwykle ważną instytucję prawa, która przyczynia się do stymulowania procesów rozwoju gospodarczego, dlatego też koniecznością było

\footnotetext{
${ }^{41}$ M. Zajęcki, op. cit., s.157-158.

42 Ibidem.

43 J. Topolski, Wyjaśnianie historyczne w świetle dyskusji filozoficznych i praktyki historyków, [w:] Poznańskie Studia z Filozofii Humanistyki, 12, 1992, s. 216.

44 F. Zedler, Prawo upadłościowe i naprawcze. Wprowadzenie, Kraków, 2003, s. 20.
} 
uchwalenie nowej regulacji. Nastąpiło to wraz z wejściem w życie ustawy Prawo upadłościowe i naprawcze z dnia 28 lutego 2003 r.

Istotne dla drugiego etapu badań, prowadzonych zgodnie z ogólnym modelem badań historycznoprawnych, jest określenie motywów i celów prowadzenia nowej regulacji, a mianowicie uchwalenia ustawy prawo upadłościowe i naprawcze z dnia 28 lutego 2003 r. Jak to zostało wskazane, motywacją prawodawcy, w tym przypadku, było urzeczywistnienie założeń gospodarki wolnorynkowej.

Pozostając jeszcze, w okresie obowiązywania PrUpadNapr warto rozważyć pod kątem intencji prawodawcy wprowadzenie w 2008 r. konstrukcji upadłości konsumenckiej. Nowelizacja PrUpadNapr z 2008 r. stanowiła pierwszą próbę adaptacji do polskiego prawa tzw. idei ,nowego startu”. Rosnąca podaż na ciągle urozmaicane usługi finansowe - kredyty, pożyczki, sprzedaż ratalna - ściśle skorelowana z popytem na dobra normalne i luksusowe, przyczyniła się do proporcjonalnego wzrostu zadłużenia społeczeństwa, a w szczególności gospodarstw domowych (uwaga na tle etapu pierwszego modelu). Dlatego wprowadzenie do systemu prawnego instytucji umożliwiającej skuteczne regulowanie egzekwowania zobowiązań gospodarstw domowych, uwzględniającej przy tym najpełniej interesy zarówno wierzyciela, jak również dłużnika oraz zapewniając możliwość oddłużenia rzetelnego konsumenta, było koniecznością. Powiększające się zadłużenie osób fizycznych, niebędących przedsiębiorcami, nie stanowiło jedynej przyczyny nowelizacji PrUpadNapr. Większość dłużników-konsumentów niewypłacalnych w okresie pisania projektu z 2003 r., zaciągało zobowiązania podczas występowania inflacji. Dostrzec należy również brak świadomości, nieumiejętność sprawnego funkcjonowania na wolnym rynku tuż po dokonanej rewolucji ustrojowej oraz ukierunkowany na zysk banków system regulacji okołokredytowej. Wobec dostrzeżonych przesłanek zasadne było stwierdzenie, iż doszło do „niesłusznego wyzysku konsumentów”. Zaciągnięte kredyty okazały się dla konsumentów zobowiązaniami, które dożywotnio zaprzepaściły szanse na „normalne życie i funkcjonowanie w społeczeństwie”. Wobec wskazanych uwag, można stwierdzić, że motywacją prawodawcy było dążenie do równości, zatarcie różnic społecznych oraz zachowanie sprawiedliwości. Podstawowym czynnikami dokonania przedmiotowej regulacji były czynniki socjalne i społeczne.

Kolejnym etapem rozwoju prawa insolwencyjnego w Polsce jest duża nowelizacja dokonana w 2016 r., również i tu można pokusić się o rekonstrukcje motywów prawodawcy, stanowić to będzie jedynie sygnalizacje, ponieważ są to rozwiązania obecnie obowiązujące, a zatem nie stanowią podstawowego przedmiotu badań historycznoprawnych. Głównym założeniem nowelizacji było wprowadzenie skutecznych instrumentów pozwalających na przeprowadzenie restrukturyzacji przedsiębiorstwa dłużnika i zapobieżenie jego likwidacji. Uzasadniano to faktem, iż zachowanie przedsiębiorstwa dłużnika w wielu przypadkach jest znacznie korzystniejsze dla wierzycieli niż jego likwidacja. Zachowanie przedsiębiorstwa dłużnika 
ponadto, pozwala na zachowanie miejsc pracy oraz możliwość nieprzerwanego realizowania kontraktów. Są do podstawowe czynniki społeczne i gospodarcze, które przesądziły o wprowadzeniu nowej formy postępowań restrukturyzacyjnych do polskiego systemu prawa insolwencyjnego.

\section{Uogólnienie prawidłowości rządzących procesami prawodawczymi i formułowanie praw nauki rządzących ewolucją systemów prawnych}

Prawo jako fenomen społeczny, nie jest jedynie sumą instytucji prawnych. Prawo w ujęciu przyjętym w niniejszym opracowaniu stanowi tzw. fakt kulturowy. Dlatego trzeci etap ogólnego modelu badań historycznoprawnych jest ukoronowaniem trudu włożonego w ustalanie faktów, interpretowanie źródeł i rekonstruowanie motywacji prawodawców ${ }^{45}$. Ustalenia poczynione w dwóch pierwszych etapach służyć mają wyjaśnieniu ewolucji kultur prawnych. Kultura prawna, to coś więcej niż tylko system prawny, dlatego nie można ograniczać przesłanek wyjaśniania wyłącznie do zrekonstruowanych instytucji (systemem) i motywacji prawodawców. Na tym etapie należy uwzględnić dodatkowe przesłanki, zarówno „,historycznoprawne”, jak i „ogólne”. Przesłanki „historycznoprawne”, to między innymi są postawy ludzi wobec prawa, edukacja prawnicza, dorobek jurysprudencji itd. Natomiast przesłanki „ogólne”, to potencjalnie wszelkie ustalenia nauk historycznych (np. historii gospodarczej, wojskowości, religii itd.), które nie są związane bezpośrednio z zagadnieniami prawnymi, ale dostarczają elementy do tworzonych modeli ewolucji porządków prawnych ${ }^{46}$.

Na podstawie przeprowadzonej analizy rozwoju prawa insolwencyjnego w ustawodawstwie polskim, można pokusić się o sformułowanie dwóch tendencji rozwojowych tej dziedziny prawa. Po pierwsze, należy wskazać na coraz większy prymat postępowań restrukturyzacyjnych (naprawczych), mających na celu zachowanie funkcjonującego przedsiębiorstwa dłużnika. Postępowania restrukturyzacyjne i postępowanie upadłościowe pozostają w funkcjonalnym związku, ustawodawca przyznaje jednaka obecnie prymat postepowaniom pozwalającym dłużnikom uniknąć ogłoszenia upadłości $i^{47}$. Każde z wskazanych postepowań reguluje skutki niewypłacalności i możliwość zapewnienia zaspokojenia wierzycieli dłużnika, ale służą osiągnieciu innych celów, definiowanych jako osiągniecie stanu rzeczy, który jeszcze nie istnieje, a jego osiągnięcie może nastąpić w wyniku podejmowania określonych działań, zachowań, mających doprowadzić do zamierzonego i pożą-

${ }^{45}$ M. Zajęcki, op. cit., s. 158.

46 Ibidem.

${ }^{47}$ I. Gil, Prymat postepowań restrukturyzacyjnych przed postępowaniem upadłościowym [w:] red. E. Marszałkowska-Krześ, A. Machnikowska, J. Kruczalak-Jankowska, I. Gil (red.), Postępowanie upadłościowe: wspótczesne problemy stosowania, s. 24. 
danego skutku ${ }^{48}$. Obecne regulacje przyznają prymat postępowaniom restrukturyzacyjnym w rozwiązywaniu konfliktu występującemu miedzy interesem dłużnika (zachowaniem przedsiębiorstwa dłużnika) a interesem wierzycieli (zaspokojeniem w jak najwyższym stopniu). Po drugie można zauważyć tendencje do rozszerzania zakresu podmiotowego postępowań insolwencyjnych, w szczególności w odniesieniu do podmiotów, które nie prowadzą działalności gospodarczej-konsumentów.

Czas pokaże, czy tendencje silnie promujące restrukturyzacje przedsiębiorców i oddłużenie osób fizycznych nieprowadzących działalności gospodarczej jest tendencją słuszną i przyczyni się do realizacji zakładanych celów.

\section{PODSUMOWANIE}

Model ogólnych badań historycznoprawnych w zaprezentowanym ujęciu stanowi doskonałe narzędzie do przeprowadzenia badań w sposób usystematyzowany i dogłębny, a poczynione w ramach niego założenia zapewniają, że wynik badań - sformułowane prawa nauki rządzące ewolucją danej dziedziny regulacji prawnej będą w pełni uzasadnione oraz cechować się będą odpowiednią mocą predektywną, tzn. zdolnością do formułowania prognoz, przewidywania konkretnych zdarzeń. Dzięki temu, przyjmując umiarkowaną wersję sensu empirycznego, ukształtowaną pod wpływem hipotetyzmu K. R. Poppera, można stwierdzić, iż twierdzenia ogólne formułowane w ogólnym modelu badań historycznoprawnych mają sens empiryczny, a co zadym idzie badania historycznoprawne są badaniami empirycznymi.

\section{BIBLIOGRAFIA}

Bator A. [w:] Wprowadzenie do nauk prawnych. Leksykon tematyczny, red. A. Bator, Warszawa 2012; Gil I., Prymat postepowań restrukturyzacyjnych przed postępowaniem upadłościowym [w:] red. E. Marszałkowska-Krześ, A. Machnikowska, J. Kruczalak-Jankowska, I. Gil (red.), Postępowanie upadtościowe: wspótczesne problemy stosowania.

Harla A.G, Prawo upadtościowe i naprawcze. Zarys wykładu, Warszawa 2011.

Kmita J., Wyktady z logiki i metodologii nauk, Warszawa 1973.

Koenner M., Syndyk masy upadłości, Sopot 1999.

Kotarbiński T., Traktat o dobrej robocie, Wrocław-Warszawa-Kraków 1965.

Kula W., Problemy i metody historii gospodarczej, Warszawa 1983.

Nowak L., Interpretacja prawnicza. Studium z metodologii prawoznawstwa, Warszawa 1973.

Nowak L., U podstaw teorii socjalizmu, Poznań 1991.

Nowak L., Wstęp do idealizacyjnej teorii nauki, Warszawa 1977.

Patryas W., Idealizacyjny charakter interpretacji humanistycznej, Poznań 1979.

Pomorski J., W poszukiwaniu modelu historii teoretycznej, Lublin 1984.

${ }^{48}$ T. Kotarbiński, Traktat o dobrej robocie, Wrocław-Warszawa-Kraków 1965, s. 115. 
Popper K. R., Wiedza obiektywna, Warszawa 2002

Świeboda Z., Komentarz do prawa upadłościowego i prawa o postępowaniu układowym, Warszawa 1996.

Topolski J., Teoria wiedzy historycznej, Poznań 1983.

Topolski J., Wyjaśnianie historyczne w świetle dyskusji filozoficznych i praktyki historyków, [w:] Poznańskie Studia z Filozofii Humanistyki, 12, 1992.

Witosz A.J. [w:] System prawa handlowego, tom 6, Prawo restrukturyzacyjne i upadtościowe, red. A. Hrycaj, A. Jakubecki, A. Witosz, Warszawa 2016.

Wronkowska S., Ziembiński Z., Zarys teorii prawa, Poznań 2001.

Zajęcki M., Przedmiot badań nauk historycznoprawnych (na przykładzie pokoju augsburskiego jako fenomenu historycznego i prawnego) [w:] CUIUS BEGIO, EIUS RELIGIO? Zjazd Historyków Państwa i Prawa, Lublin 2006.

Zalewska A., Teoria źródła archeologicznego i historycznego we wspótczesnej refleksji metodologicznej, Lublin 2005.

Zedler F., Prawo upadłościowe i naprawcze. Wprowadzenie, Kraków, 2003.

Zieliński M., Interpretacja jako proces dekodowania tekstu prawnego, Poznań 1972.

Zieliński M., Interpretacja jako proces dekodowania tekstu prawnego, Poznań 1972.

Zieliński M., Właściwości derywacyjnej koncepcji wykładni [w:] Zeszyty Naukowe Uniwersytetu Szczecińskiego. Roczniki Prawnicze, 1998, nr 2.

Ziembiński Z., Problemy podstawowe prawoznawstwa, Warszawa 1980.

Zirk-Sadowski M., Prawo a uczestniczenie w kulturze, Łódź 1998.

\section{SUMMARY}

The article analyzes the development of the Polish bankruptcy law of bankruptcy law in the legal historical aspect. The first part discusses the research model used in the historical-legal research model from the perspectives of the idealization concept of science. Three stages of the development of bankruptcy law were presented. The analysis referred to both legal acts and non-source knowledge, which is, inter alia, knowledge of economic conditions. The article shows that it is not possible to reconstruct the normative content in isolation from the social and economic conditions. On the basis of the analysis of the development of the broadly understood bankruptcy law in Polish legislation, two trends in the development of this area of law have been demonstrated in the article. The first one pointing to the primacy of restructuring (repairing) proceedings aimed at preserving a functioning debtor's enterprise. The second, concerning the extension of the subjective scope of bankruptcy and restructuring proceedings, to entities that do not conduct business. Time will tell if these trends are right and will contribute to the objectives.

Key words: bankruptcy law, legal history, evolution of bankruptcy law institutions, political transformation. 